\title{
Evaluation of Different Novel Chemicals against Panama Wilt of Banana Incited by Fusarium oxysporum f. sp. cubense TR4
}

\author{
Kewal Chand* and S. K. Singh \\ Department of Plant Pathology, Dr. Rajendra Prasad Central Agricultural University, \\ Pusa, Samastipur, Bihar, India \\ *Corresponding author
}

\begin{tabular}{|c|}
\hline Keywords \\
\hline $\begin{array}{l}\text { Fusarium } \\
\text { oxysporum f.sp. } \\
\text { cubense TR4 (FOC } \\
\text { TR4), Novel } \\
\text { chemicals, Panama } \\
\text { wilt }\end{array}$ \\
\hline Article Info \\
\hline $\begin{array}{l}\text { Accepted: } \\
10 \text { January } 2021 \\
\text { Available Online: } \\
10 \text { February } 2021\end{array}$ \\
\hline
\end{tabular}

\section{A B S T R A C T}

Total six novel chemicals viz., Carbendazim (Bavistin), Hexaconazole (Convax plus), Tebuconazole (Folicur), Tebuconazole 50\%+ Trifloxystrobin 25\% (Nativo), Fosetyl-Al (Aliette) and Fluopyram 17.7\%+ Tebuconazole17.7\% (Luna) were evaluated against Fusarium oxysporum f. sp. cubense TR4 at 50, 100, and $150 \mathrm{ppm}$ concentration. Data revealed that the $100 \%$ inhibition was recorded in Tebuconazole $50 \%+$ Trifloxystrobin $25 \%$ even at $50 \mathrm{ppm}$ followed by Fluopyram $17.7 \%+$ Tebuconazole $17.7 \%$ and Tebuconazole with $100 \%$ inhibition over control at $150 \mathrm{ppm}$. The Minimum inhibition was found in the Carbendazim with $43.05 \%$ inhibition over control at $150 \mathrm{ppm}$. Same chemicals were tested at $0.2 \%$ concentration against Panama wilt of banana under pot condition in poly house. Among the novel chemicals, Tebuconazole 50\% + Trifloxystrobin $25 \%$ was found most effective against Fusarium oxysporum f. sp. cubense TR4, in which wilt symptom was not observed up to 78 days after inoculation (DAI) in cv. Grand naine followed by Tebuconazole in which wilt disease was not found before 55 DAI while in Hexaconazole 52 DAI, Fosetyl-Al 50 DAI, Carbendazim 48 DAI whereas in Fluopyram $17.7 \%+$ Tebuconazole $17.7 \%$ wilt symptoms were appeared in 47 DAI. In control where no treatment was applied wilt symptom was seen in 21 days with a $96 \%$ wilt index. Maximum $77.09 \%$ inhibition over control was recorded in Tebuconazole $50 \%+$ Trifloxystrobin $25 \%$ followed by $52.09 \%$ in Fluopyram $17.7 \%+$ Tebuconazole $17.7 \%, 50.00 \%$ in Tebuconazole, $48.96 \%$ in Hexaconazole, $45.83 \%$ in Carbendazim and minimum $29.17 \%$ in Fosetyl-Al.

\section{Introduction}

Banana is one of the important commercial fruit crops grown in the tropical and subtropical regions not only in India but also in the world. Production and productivity per unit area in India is very low. Low production and productivity may be due to many factors, among them diseases are playing a major role.
Many micro-organisms caused diseases like viruses, bacteria, fungi and nematodes. The most important and economically destructive disease is "Panama wilt", it is also called as Fusarium wilt incited by Fusarium oxysporum f. sp. cubense. The Panama wilt disease is most destructive due to the emergence of new pathogenic race i.e. Tropical race (TR4). Panama wilt disease 
incidence in the Dwarf Cavendish group (Grand naine) of bananas was known to occur in state Bihar since 2015. Thangavelu et al., (2019) reported that the existence of tropical race 4 in India. FOC TR4 observed in Katihar and Purnea districts of Bihar in Cavendish group of bananas cultivars Robusta and Grand naine. Damodaran et al., (2019) reported that the FOC TR4 present in Uttar Pradesh in September 2017.

\section{Materials and Methods}

Six fungicides and novel chemicals were evaluated in the laboratory against the pathogen of Panama wilt Fusarium oxysporum f. sp. cubenseTR4 in vitro. Their chemical name, trade name, and formulation are given in (Table-1). For the using of poison food techniques $100 \mathrm{ml}$ sterilized potato dextrose (PD broth) medium was mixed with $5 \mathrm{mg}(0.005 \mathrm{ml}), 10 \mathrm{mg}(0.01 \mathrm{ml})$ and $15 \mathrm{mg}$ $(0.015 \mathrm{ml})$ of fungicides or novel chemicals separately to get @ concentration of 50, 100 and 150ppm. Take $20 \mathrm{ml}$ of each concentration of media was pore in each sterilized Petri plate and allow solidifying in laminar airflow cabinet. After solidification, $5 \mathrm{~mm}$ disc having seven days old pure culture of test fungus i.e. Fusarium oxysporum f. sp. cubenseTR 4 was placed in the centre of Petriplates in inverse direction and incubated at 28 $\pm 2{ }^{\circ} \mathrm{C}$. Each treatment was replicated three times with control in which no chemical was added in the medium. The radial growth of pathogen Fusarium oxysporum f. $\mathrm{sp}$. cubenseTR4 was note after $24 \mathrm{hrs}$ of inoculation and ensuing observation was recorded at $48 \mathrm{hrs}$ of interval till complete growth of the fungal pathogen in control i.e. $240 \mathrm{hrs}$ and percent inhibition was determined by the following formula given by Vincent (1927).

$$
I=\left(\frac{C-T}{C}\right) \times 100
$$

Where,

$\mathrm{I}=$ Percent growth inhibition

$\mathrm{C}=$ Control Petri plate colony diameter

$\mathrm{T}=$ Treated Petri plate colony diameter

The percent inhibition data were statistically analysed by using completely randomized design (C.R.D)

\section{Results and Discussion}

Total six fungicides viz., Carbendazim, Hexaconazole, Tebuconazole, Tebuconazole $50 \%+$ Trifloxystrobin 25\%, Fosetyl-Al and Fluopyram $17.7 \%+$ Tebuconazole $17.7 \%$ were evaluated against Fusarium oxysporum f.sp. cubense TR4 at 50, 100 and $150 \mathrm{ppm}$ concentration. The radial growth was measured after $24 \mathrm{hrs}$ of inoculation and subsequent observations were recorded at five and ten days intervals till full growth of the pathogen in control i.e. $240 \mathrm{hrs}$. Complete inhibition of radial growth was observed in Nativo (Tebuconazole 50\%+ Trifloxystrobin 25\%), Luna (Fluopyram $17.7 \%+$ Tebuconazole 17.7) and Folicur (Tebuconazole) at 50, 100 and $150 \mathrm{ppm}$ respectively (Fig. 1 and 2).

Percent inhibition over control was calculated based on the final observation. The result shows that all the fungicides at 50, 100 and $150 \mathrm{ppm}$ concentration significantly inhibited the growth of Fusarium oxysporum f.sp. cubense TR4 when compared with control. Data revealed that the $100 \%$ inhibition was recorded in Nativo (Tebuconazole50\%+ Trifloxystrobin 25\%) even at $50 \mathrm{ppm}$ followed by Luna (Fluopyram 17.7\%+ Tebuconazole17.7\%) and Folicur (Tebuconazole) with $100 \%$ inhibition over control at $150 \mathrm{ppm}$. The Minimum inhibition was found in the Carbendazim (Bavistin) with $43.05 \%$ inhibition over control at $150 \mathrm{ppm}$ (Table-2). 
Different novel chemicals were tested at $0.2 \%$ concentration against Fusarium wilt of banana under pot condition in the poly house. Mass culture of Fusarium oxysporum f.sp. cubense TR4 was multiplied on sand corn medium added to steam-sterilized soil (15 psi for 30 minutes) in pots @ 5\% (w/w). Soil mixture with inoculums served as a control pot. Each pot was planted with a one-monthold Grand naine (AAA) tissue culture banana plant. The data was recorded based on the first appearance of symptoms of the disease, percent incidence of wilt index, and percent inhibition over control.

Table.1 Fungicides and novel chemicals details used against the pathogen Fusarium oxysporum f. sp. cubenseTR4 causal agent of Panama wilt of banana

\begin{tabular}{|l|l|l|}
\hline Trade name & Chemical name & Formulation \\
\hline Bavistin & Carbendazim & $50 \% \mathrm{WP}$ \\
\hline Convax plus & Hexaconazole & $5 \% \mathrm{EC}$ \\
\hline Folicur & Tebuconazole & $250 \mathrm{EC}$ \\
\hline Nativo & Tebuconazole 50\% +Trifloxystrobin 25\% & $75 \mathrm{WG}$ \\
\hline Aliette & Fosetyl-Al & $80 \% \mathrm{WP}$ \\
\hline Luna & Fluopyra 17.7\% + Tebucanazole 17.7\% & $400 \mathrm{SC}$ \\
\hline
\end{tabular}

Table.2 Effectiveness of different novel chemicals against Fusarium oxysporum f.sp. cubense TR4 causing Panama wilt of banana in vitro

\begin{tabular}{|c|c|c|c|c|c|c|}
\hline \multirow{2}{*}{\multicolumn{2}{|c|}{ Treatments }} & \multirow{3}{*}{\begin{tabular}{|c|c} 
Cons. \\
$(\mathbf{p p m})$
\end{tabular}} & \multicolumn{4}{|c|}{ Radial growth $(\mathrm{mm}) *$ at different hrs } \\
\hline & & & \multirow{2}{*}{$\begin{array}{c}24 \mathrm{hrs} \\
3.9\end{array}$} & \multirow{2}{*}{$\begin{array}{c}120 \mathrm{hrs} \\
26.4\end{array}$} & \multirow{2}{*}{$\begin{array}{c}240 \mathrm{hrs} \\
58.2\end{array}$} & \multirow{2}{*}{$\begin{array}{c}\text { Inhibition over control (\%) } \\
34.75\end{array}$} \\
\hline $\mathbf{T}_{1}$ & Bavistin (Carbendazim 50\% WP) & & & & & \\
\hline & & 100 & 2.7 & 23.0 & 54.3 & 39.12 \\
\hline & & 150 & 0.8 & 20.0 & 50.8 & 43.05 \\
\hline \multirow[t]{3}{*}{$\mathbf{T}_{2}$} & \multirow{3}{*}{ Convax plus (Hexaconazole 5\% EC) } & 50 & 3.6 & 27.3 & 47.6 & 46.63 \\
\hline & & 100 & 2.6 & 22.6 & 44.1 & 50.56 \\
\hline & & 150 & 1.2 & 19.8 & 41.3 & 53.69 \\
\hline \multirow{3}{*}{$\mathbf{T}_{3}$} & \multirow{3}{*}{$\begin{array}{l}\text { Folicur } \\
\text { (Tebuconazole 250 EC) }\end{array}$} & 50 & 0.2 & 0.7 & 1.4 & 98.43 \\
\hline & & 100 & 0.0 & 0.0 & 0.0 & 100.0 \\
\hline & & 150 & 0.0 & 0.0 & 0.0 & 100.0 \\
\hline \multirow[t]{3}{*}{$\mathbf{T}_{4}$} & \multirow{3}{*}{$\begin{array}{l}\text { Nativo(Tebuconazole } 50 \%+\text { Trifloxystrobin } \\
25 \% 75 \text { WG) }\end{array}$} & 50 & 0.0 & 0.0 & 0.0 & 100.0 \\
\hline & & 100 & 0.0 & 0.0 & 0.0 & 100.0 \\
\hline & & 150 & 0.0 & 0.0 & 0.0 & 100.0 \\
\hline \multirow[t]{3}{*}{$\mathbf{T}_{5}$} & \multirow{3}{*}{$\begin{array}{l}\text { Aliette } \\
\text { (Fosetyl-Al 80\% WP) }\end{array}$} & 50 & 6.7 & 25.4 & 49.4 & 44.61 \\
\hline & & 100 & 5.3 & 22.6 & 45.9 & 48.54 \\
\hline & & 150 & 2.0 & 13.4 & 41.5 & 53.47 \\
\hline \multirow[t]{3}{*}{$\mathbf{T}_{6}$} & \multirow{3}{*}{$\begin{array}{l}\text { Luna } \\
\text { (Fluopyram } 17.7 \%+\text { Tebuconazole } 17.7 \% \\
\text { 400 SC) }\end{array}$} & 50 & 4.2 & 22.1 & 36.2 & 59.41 \\
\hline & & 100 & 0.1 & 0.4 & 1.1 & 98.76 \\
\hline & & 150 & 0.0 & 0.0 & 0.0 & 100.0 \\
\hline $\mathbf{T}_{7}$ & Control & & 13.1 & 36.8 & 89.2 & \\
\hline \multicolumn{2}{|c|}{ CD at $5 \%$} & & 0.14 & 0.56 & 2.25 & 1.38 \\
\hline \multicolumn{2}{|c|}{ S.Em. $( \pm)$} & & 0.05 & 0.19 & 0.78 & 0.48 \\
\hline \multicolumn{2}{|c|}{ C.V. (\%) } & & 3.38 & 2.44 & 4.58 & 1.17 \\
\hline
\end{tabular}

*Mean of three replications 
Table.3 Effectiveness of different novel chemicals against Fusarium oxysporum f. sp. cubense TR4 causing Panama wilt of banana under pot condition

\begin{tabular}{|l|l|c|c|c|}
\hline \multicolumn{1}{|c|}{ Fungicides } & $\begin{array}{c}\text { First appearance of } \\
\text { disease (DAT) }\end{array}$ & Incidence (\%) & $\begin{array}{c}\text { Inhibition over } \\
\text { control (\%) }\end{array}$ \\
\hline $\mathbf{T}_{\mathbf{1}}$ & Bavistin (Carbendazim50\% WP) & 48 & 52 & 45.83 \\
\hline $\mathbf{T}_{\mathbf{2}}$ & Convex plus (Hexaconazole 5\% EC) & 52 & 49 & 48.96 \\
\hline $\mathbf{T}_{\mathbf{3}}$ & Folicure (Tebuconazole 250 EC) & 55 & 48 & 50.00 \\
\hline $\mathbf{T}_{\mathbf{4}}$ & $\begin{array}{l}\text { Nativo(Tebuconazole50\%+ } \\
\text { Trifloxystrobin 25\% 75 WG) }\end{array}$ & 78 & 22 & 77.09 \\
\hline $\mathbf{T}_{\mathbf{5}}$ & Aliette (Fosetyl-A1 80\% WP) & 50 & 68 & 29.17 \\
\hline $\mathbf{T}_{\mathbf{6}}$ & $\begin{array}{l}\text { Luna(Fluopyram17.7\%+ } \\
\text { Tebuconazole17.7\% 400 SC) }\end{array}$ & 47 & 46 & 52.09 \\
\hline $\mathbf{T}_{\mathbf{7}}$ & Control & 21 & 96 & \\
\hline CD at 5\% & 1.77 & 1.77 & 0.98 \\
\hline S.Em. ( $\mathbf{( \pm )}$ & 0.58 & 0.58 & 0.31 \\
\hline C.V. $\mathbf{( \% )}$ & 2.00 & 1.84 & 1.08 \\
\hline
\end{tabular}

*Mean of three replications

Fig.1 Effectiveness of different novel chemicals against Fusarium oxysporum f.sp. cubense TR4 causing Panama wilt of banana in vitro

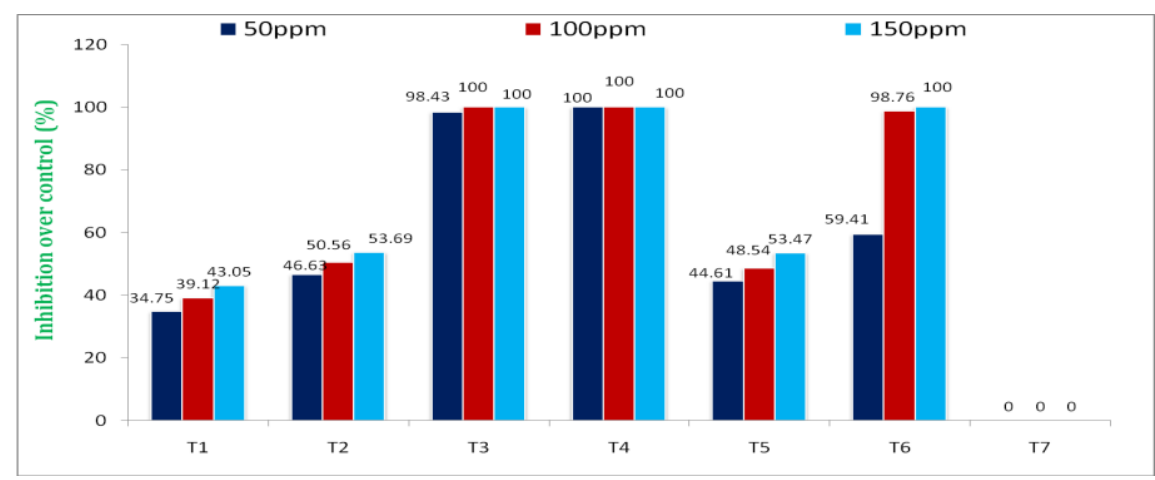

Fig.2 Effectiveness of different novel chemicals against Fusarium oxysporum f.sp. cubense TR4 causing Panama wilt of banana under pot condition

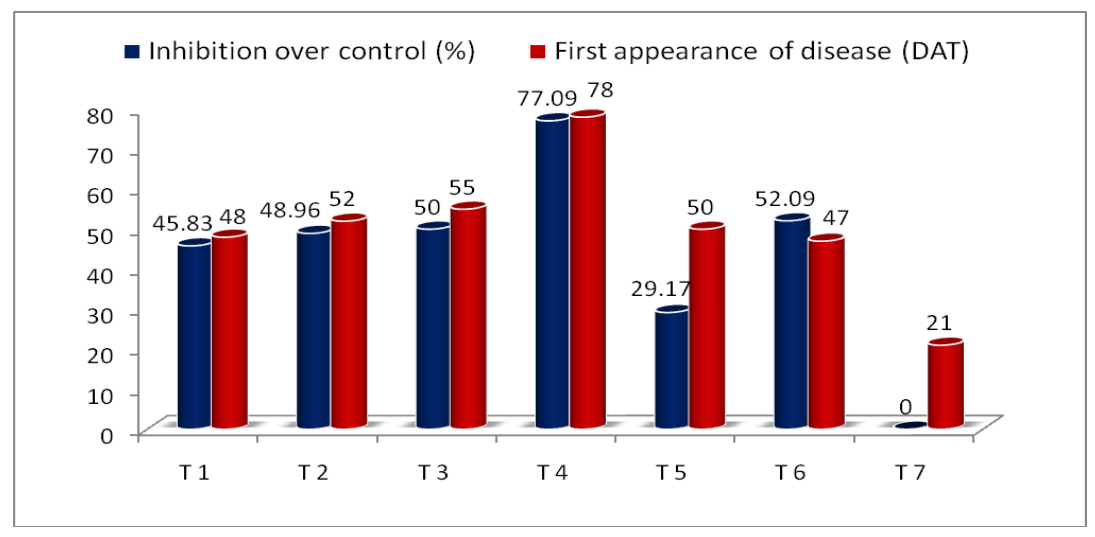


Plate.1 Effectiveness of different novel chemicals against Fusarium oxysporum f.sp. cubense TR4 causing Panama wilt of banana in vitro

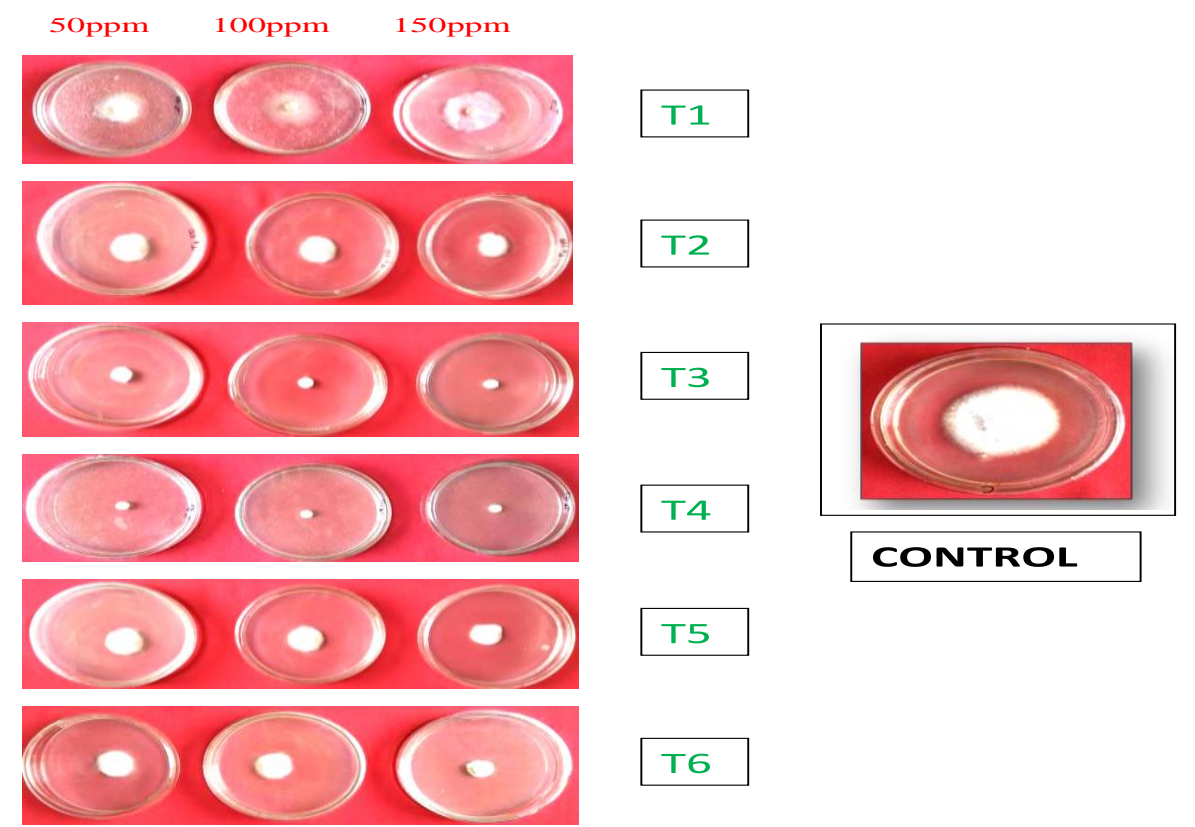

Plate.2 Effectiveness of different novel chemicals against Fusarium oxysporum f.sp. cubense TR4 causing Panama wilt of banana under pot condition
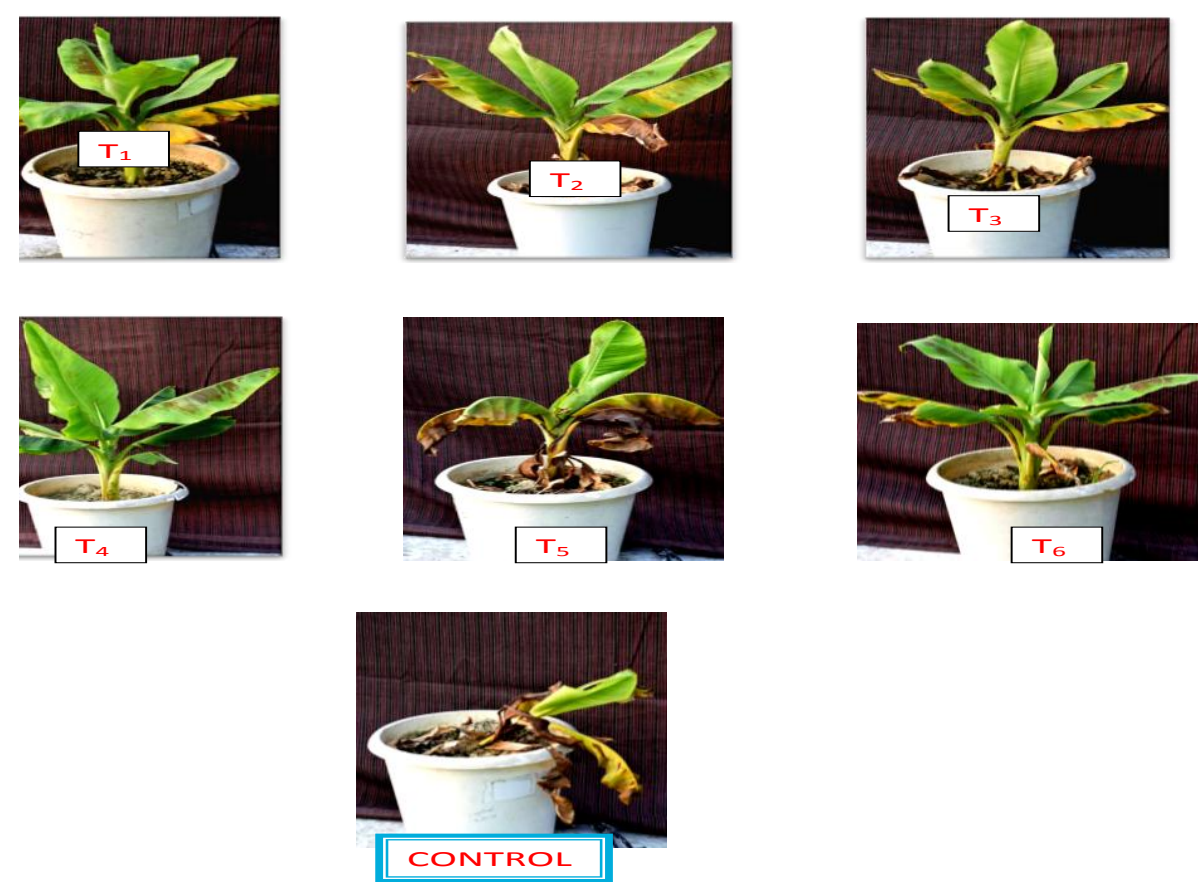
Among the novel chemicals, Nativo (Tebuconazole 50\% + Trifloxystrobin 25\%) was found most effective against Fusarium oxysporum f.sp. cubense TR4, in which wilt symptom was not observed up to 78 days after inoculation (DAI) in cv. Grand naine followed by Folicur (Tebuconazole) in which wilt disease was not found in 55 DAI while in Hexaconazole (Convax plus) 52 DAI, Fosetyl-Al (Aliette) 50 DAI, Carbendazim (Bavistin) 48 DAI whereas in Luna (Fluopyram $17.7 \%+$ Tebuconazole17.7\%) wilt symptoms were appeared in 47 DAI.

In control where no treatment was applied wilt symptom was seen in 21 days with a $96 \%$ wilt index. Maximum $77.09 \%$ inhibition over control was recorded in Nativo (Tebuconazole $50 \%+$ Trifloxystrobin 25\%) followed by $52.09 \%$ in Luna (Fluopyram $17.7 \%+$ Tebuconazole17.7\%), $50.00 \%$ in Folicur (Tebuconazole), $48.96 \%$ in Hexaconazole (Convax plus) $45.83 \%$ in Carbendazim (Bavistin) and minimum $29.17 \%$ in FosetylAl (Aliette) (Table-2).

Present findings showed agreement with observations of many earlier workers. Li chi et al., (2008) evaluated nine different fungicides, including $45 \%$ Sportak (carbendazim + prochloraz), 50\% Sporgon (prochloraz), 50\% Ipredine, 50\% thiram, 50\% carbendazim, $\quad 15 \%$ Omiral, $2.5 \%$ Tilt (propiconazole) etc. and observed that $45 \%$ Sportak, 2.5\% Tilt and 50\% Sporgon had effectiveness, greatly reducing the pathogen; their EC50/mg/L values were 0.00094, 0.039 and 0.4895 respectively. Mengal et al., (2016) evaluated five different fungicides against Fusarium oxysporum. The result indicate that Nativo was found most effective in prevent the colony growth of fungus (3.3mm) followed by Alliete $(8.66 \mathrm{~mm})$ and Cabriotop (19.00mm).

Keerio et al., (2017) reported that native was found maximum effective inhibition in linear colony growth of the fungus at its highest and lowest doses $7.00 \mathrm{~mm}$, followed by alliete $16.1 \mathrm{~mm}$, whereas, romeo and cabriotop found less effective as compared to nativo and alliete. Dragon was found least effective as compared to other four fungicides which inhibit at highest dose the linear colony growth was found $64.467 \mathrm{~mm}$ against tested fungi. Niwas et al., (2020) conducted experiment with six different fungicides viz. azoxystrobin, carbendazim and propiconazole used against Fusarium oxysporum f.sp. cubense incited Panama wilt disease of banana. The result revealed that among the fungicides used, carbendazim at 500 and 750 ppm inhibited cent percent mycelial growth of Fusarium oxysporum f.sp. cubense followed by azoxystrobin $32.96,11.30,8.12$ and 7.16 $\mathrm{mm}$ at 100, 250, 500 and $750 \mathrm{ppm}$ respectively.

\section{References}

Damodaran, T., Mishra, V.K., Jha, S.K., Gopal, R., Rajan, S. and Ahmed, I. 2019. First Report of Fusarium wilt in banana caused by Fusarium oxysporum f. sp. cubense Tropical Race 4 in India. Plant Disease "First Look" paper.

Keerio, Azizullah., Nizamani,Ahmed Zubair., Hussain,Shahid., Rafiq, Muhammad., Iqbal Sohail., Keerio, Azhauddin 2017. Efficacy of some chemical fungicides aginst fusarial wilts of sunflower in vitro condition. Int. J. Botany Studied. Vol:2(5) pp:80-85.

Li, chi., Yu, Li., Chen-Yong Qin and XingShanshan 2008. Examination of the effectiveness of Fungicides for killing the pathogen of banana wilt disease in laboratory. South China Fruits. (2):4445.

Mengal S.A., Hussain S., Ali M.A., Nisa T., khetran R., Dahar G.Y., Zaib U., Mushwani N.S., keerio A., Maari S.A. 2016. Investigations on Fusarium wilt disease of mango nursery and Its In- 
Vitro control by applying different fungicides on the linear colony growth of Fusarium oxysporium. International Journal of Fauna and Biological Studies 2016; 3(3): 107-112.

Niwas R., Chand G. and Azad C.S., 2020. In vitro evaluation of fungicides against growth of Fusarium oxysporum f. sp. cubense causing Panama wilt disease of Banana. International Journal of Chemical Studies 2020; 8(1): 191-194.
Thangavelu R., D. Mostert, M. Gopi, P. Ganga Devi, B. Padmanaban, A. B. Molina and A. Viljoen 2019. First detection of Fusarium oxysporum f. sp. cubense tropical race 4 (TR4) on Cavendish banana in India. Eur J Plant Pathol (2019) 154:777-786.

Vincent, J. M. 1927. Determination of percent inhibition in vitro. Nature. 159:850.

\section{How to cite this article:}

Kewal Chand and Singh, S. K. 2021. Evaluation of Different Novel Chemicals against Panama Wilt of Banana Incited by Fusarium oxysporum f. sp. cubense TR4. Int.J.Curr.Microbiol.App.Sci. 10(02): 951-957. doi: https://doi.org/10.20546/ijcmas.2021.1002.113 